\title{
Penerapan Vector Auto Regression (VAR) Pada Jakarta Islamic Index dan Variabel Makro Ekonomi
}

\author{
Inayah S. Ratih, Mukhtar Adinugroho, dan Sri Herianingrum \\ Magister Sains Ekonomi Islam, Fakultas Ekonomi dan Bisnis, Universitas Airlangga \\ E-mail: inayah.swasti.ratih-2018@pasca.unair.ac.id
}

\begin{abstract}
Abstrak: Penelitian ini menganalisis hubungan ekonomi makro yaitu kurs rupiah terhadap dollar, inflasi, IPI, BI Rate dan pasar modal syariah dengan menggunakan Jakarta Islamic Index. Data yang digunakan dalam penelitian ini mulai periode Januari 2006 sampai Desember 2015. Metode analisis data yang digunakan adalah Vector Autoregression (VAR). Hasil penelitian menyatakan bahwa Variabel JII secara statistic signifikan mempengaruhi Kurs, Inflasi mempengaruhi JII namun variabel JII secara statistic tidak signifikan mempengaruhi Inflasi. Variabel JII secara statistic signifikan mempengaruhi BI Rate namun tidak terjadi hubungan sebaliknya. Sedangkan variabel IPI dan JII sama-sama tidak saling mempengaruhi baik secara searah maupun dua arah. Variabel Inflasi dan Kurs, keduanya tidak saling mempengaruhi. Respon tingkat JII terhadap guncangan dari dirinya sendiri pada periode pertama yang mana berbeda pada saat periode 2 hingga periode 10 mengalami penurunan. JII lebih banyak dipengaruhi oleh Inflasi kemudian disusul oleh Kurs, kemudian BI Rate dan yang terakhir IPI.
\end{abstract}

Kata Kunci: Kurs, Inflasi, IPI, BI Rate, JII.

\section{PENDAHULUAN}

Perkembangan ekonomi Islam di Indonesia semakin meningkat dan mengarah positif. Salah satunya yaitu perkembangan industry keuangan syariah. Keuangan syariah membutuhkan banyak instrument dalam pengembangan investasi dan realisasinya. Terciptanya kondisi keuangan syariah yang positif akan berdampak positif juga terhadap perekonomian Indonesia. Hal ini disebabkan karena fungsi dari keuangan syariah adalah fungsi ekonomi sebagai penggerak sekor riil dan fungsi keuangan sebagai penggerak sector moneter. Salah satu sector moneter di industry keuangan syariah adalah pasar modal dimana dalam fungsi ekonomi pasar modal berperan sebagai sarana bertemunya investor dan pihak yang membutuhkan dana atau modal. Adapun ditinjau dari fungsi keuangan, imbalan atau return dari pasar modal dapat dirasakan manfaatnya oleh pemilik modal atau investor sesuai dengan model investasi yang dipilih.

Aturan mengenai pasar modal di Indonesia diatur dalam dalam Undang-undang Republika Indonesia Nomor 8 Tahun 1995 Tentang Pasar Modal, di mana dinyatakan bahwa Pasar Modal mempunyai peran yang strategis dalam pembangunan nasional, sebagai salah satu sumber pembiayaan bagi dunia usaha dan wahana investasi bagi masyarakat. Awal kemunculan produk-produk syariah dari pasar modal didasari dengan adanya keinginan umat Islam untuk berinvetasi sesuai dengan aturan Islam. Maka PT Danareksa Investment Management untuk menciptakan dan mulai mengoperasionalkan Danareksa Syariah pada 
tanggal 3 Juli 1997. Dilanjutkan dengan adanya kerjasama Bursa Efek Indonesia dengan PT Danareksa Investment management yang kemudian bersepakat untuk meluncurkan Jakarta Islamic Index (JII) pada tanggal 3 Juli 2000, sejak saat itu produk-produk investasi syariah terus mengalami perkembangan seperti dengan kemunculan instrument obligasi syariah (sukuk), reksadana syariah, Daftar Efek Syariah (DES) yang kemudian berubah menjadi Indeks Saham Syariah Indonesia (ISSI). Dalam laporan perkembangan Saham Syariah di Otoritas Jasa Keuangan sejak 6 tahun terakhir bisa dilihat peningkatan yang sangat positif.

Gambar 1. Perkembangan Saham Syariah Tahun 2013-2019

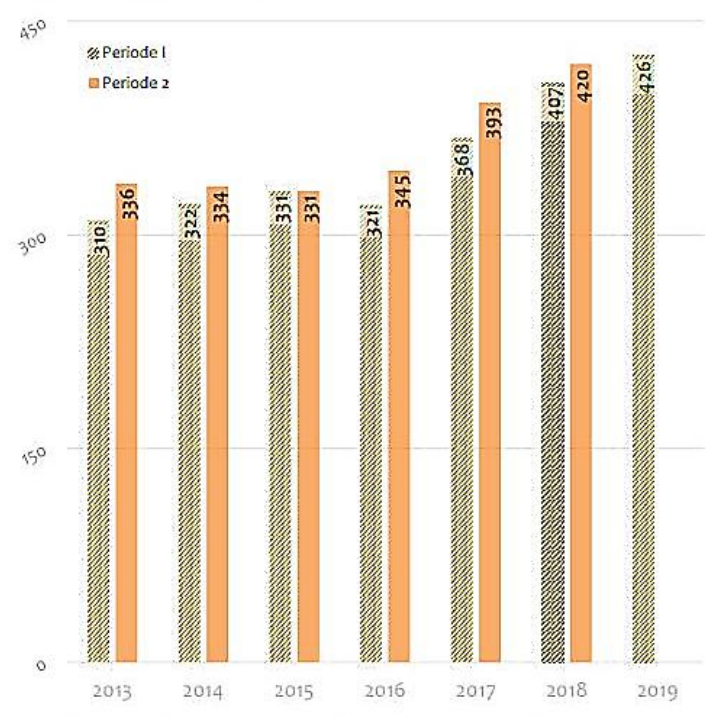

Sumber: Otoritas Jasa Keuangan (2019)

Data diatas mengindikasikan bahwa keberadaan saham syariah sangat diminati oleh para investor. Perkembangan yang positif ini bukan berarti tidak melewati berbagai guncangan-gunangan ekonomi. Pasar modal sendiri memiliki peran yang cukuppenting dalam pertumbuhan ekonomi karena interaksi ekonomi antara investor sebagai pemilik modal dengan pemilik perusahaan merupakan interaksi yang saling menguntungkan. Dana yang didapatkan dari pasar modal bisa digunakan sebagai pengembangan usaha perusahaan seperti untuk kegiatan ekspansi usahanya. Namun kebaharuan pasar modal syariah membutuhkan banyak penelitian guna menambah informasi yang bias digunakan sebagai acuan dalam berinvestasi. Beberapa variabel yang memeiliki keterkaitan dengan stabilitas pasar modal syariah yang bisa dilihat dari indeks harga saham di Jakarta Islamic Index yaitu disebabkan adanya pengaruh krisis ekonomi global dan keadaan dari perekonomian negara itu sendiri yang disebabkan variabel makroekonominya. Variabel ekonomi makro tersebut selalu mengalami fluktuasi layaknya nilai tukar rupiah terhadap dollar, tingkat inflasi, tingkat suku bunga, jumlah uang beredar, tingkat pertumbuhan ekoomi maupun kebijakan dan regulasi-regulasi pemerintah yang mudah berubah setiap periodenya sehingga akan sangat mempengaruhi stabilisai dari pasar modal. Nilai tukar rupiah terhadap dollar atau kurs akan sangat mempengaruhi stabilitas pasar modal itu sendiri dimana semakin kuat kurs 
maka perekonomian akan mengikuti. Selain itu inflasi pun yang dapat dikelandalikan melalui suku bunga dimana suku bunga yang tak mampu dikontrol mampu menggambarkan kondisi perekonomian yang kurang sehat seperti tingkat inflasi yang terlalu tinggi ataupun rendah yang akan mempengaruhi keuntungan perusahaan dan harga sahamnya.

Dalam pengendalian inflasi diperlukan satu instrumen penting yaitu BI Rate atau tingkat suku bunga acuan. Pengendalian ini akan berdampak pada kenaikan tabungan masyarakat dan biaya bnga perusahaan juga ikut meningkat sehingga perusahaan mengalami kenaikan biaya operasional dan beresiko pada peningkatan investasi karena masyarakat akan lebih memilih untuk menggunakan uangnya berinvestasi dari pada membelanjakan uangnya dengan biaya yang cukup tinggi (Kismawardi, 2013). Investasi sendiri merupakan bentuk penanaman modal secara langsung maupun tidak langsung dimana nantinya penanam modal mendapatkan keuntungan dari hasil investasi tersebut (Samsul, 2016). Oleh karena itu fungsi indeks dalam Pasar Modal menurut (Shidiq dan Setiawan, 2015) merupakan sebagai indicator trend saham, indicator tingkat keuntungan, dan sebagai tolak ukur (benchmark) kinerja suatu portofolio, memfasilitasi pembentukan portofolio dengan strategi pasif, memfasilitasi berkembangnya produk derivative. Investor membutuhkan perhatian yang besar dalam aktivitas investasi dalam pasar modal syariah terutama dengan situasi moneter dan pergerakan-pergerakan dari variable-variabel makro ekonomi seperti kurs, inflasi, Industrial Production Index, BI Rate dan Jakarta Islamic Index.

Pemilihan variable-variabel tersebut didasari karena pertama kurs rupiah yang mengindikasikan salah satu harga dalam perekonomian suatu negara dimana pengaruhnya cukup besar terhadap transaksi berjalan di variable makro ekonomi lainnya. Kedua, inflasi dimana peran inflasi tidak pernah lepas dari perekonomian baik secara moneter maupun fiscal karena inflasi sendiri berperan menunjukkan nilai kenaikan harga barang secara nasional. Ketiga variable IPI dipilih karena aktivitas sector riil berpengaruh besar terhadap perekonomian negara yang artinya variable lain akan turut berubah ketika terjadi pergerakan. Keempat, BI Rate dimana setiap kebijakan moneter tidak pernah terlepas dari penentuan variable ini, variable BI Rate juga digunakan dalam pencapaian stabilitas perekonomian. Variable kelima adalah Jakarta Islamic Index (JII) yang dipilih karena merupakan variable ekonomi makro sector moneter yang dimana didalamnya terjadi pertremuan antara pemilik modal dan pengelola modal untuk menjalankan usaha yang artinya ketika terjadi perubahan dari JII baik naik ataupun turun maka secara otomatis juga akan mempengaruhi perekonomian secara makro. Adapun atas dasar permasalahan yang telah diurakan sebelumnya maka penelitian ini dilakukan untuk menganalisis hubungan dari kedua variabel yaitu variabel makro ekonomi dengan pasar modal dimana dimana ekonomi makro yang digunakan adalah kurs rupiah terhadap dollar, inflasi, IPI, BI Rate sedangkan pasar modal syariah menggunakan Jakarta Islamic Index.

\section{KAJIAN TEORI}

Perkembangan instrument keuangan syariah dalam pasar modal berawal pada tahun 1997, dimana dimulai dari lahirnya reksadana syariah yang diprakarsai danareksa. Kemudian diluncurkanlah 30 jenis saham syariah dalam Jakarta Islamic Index (JII) dimana sesuai dengan ketentuan Islam. Ketentuan mengenai diperbolehkannya penggunaan pasar modal syariah disahkan oleh DSN MUI (Romansyah, 2015). Peluncuran JII ini merupakan 
hasil kerjasama PT. Bursa Efek Indonesia bersama dengan PT. Danareksa Investment Management (DIM). Aturan dan ketentuan-ketentuan mengenai saham syariah disusun serta mendapatkan persetujuan dari Dewan Pengawas Syariah DIM. Dalam makroekonomi dijelaskan bahwa perubahan ekonomi banyak mempengaruhi seperti pelaku ekonomi itu sendiri diantaranya rumah tangga (household), perusahaan dan pasar. Dari pengaruh yang ditimbulkan maka ekonomi makro selalu digunakan untuk menganalisis berbagai cara terbaik dalam menentukan kebijakan guna mencapai target dalam pencapaian pertumbuhan ekonomi, stabilitas harga, tenaga kerja dan keseimbangan neraca yang berkelanjutan. Variable ekonomi makro cukup luas dan kompleks namun dalam penelitian ini hanya akan menggunakan 4 variabel yang dianggap sangat memiliki pengaruh terhadap Jakarta Islamic Index, variable tersebut adalah nilai tukar Rupiah terhadap Dollar Amerika (Kurs), tingkat Inflasi, BI Rate dan Industrial Production Index (IPI). Beberapa penelitian mengenai pengaruh variabel makro terhadap Nilai Jakarta Islamic Index telah banyak dilakukan, beberapa diantaranya oleh (Wastriati, 2010) dimana periode yang digunakan mulai periode bulan Januari tahun 2003 hingga bulan Desember tahun 2009, Dari hasil penelitiannya ditunjukkan bahwa terdapat pengaruh antara variabel kurs, M2, inflasi dan PDB terhadap JII dalam jangka panjang. Sedangkan dalam jangka pendek tidak ada pengaruh antara kurs, M2 dan Inflasi terhadap nilai JII, hanya variabel PDB yang mempengaruhi nilai JII dalam jangka pendek.

Hasil yang ditunjukkan oleh (Mulyani, 2014) variabel inflasi memiliki hubungan yang positif dan signifikan terhadap Indeks Saham Syariah (ISSI). Berbeda dengan hasil yang ditunjukkan dari penelitian (Suciningtias dan Khoiroh, 2015), (Rachmawati dan Laila, 2015), (Rusbariandi, 2012), (Sakti, 2013) dimana dikemukakan bahwa inflasi berpengaruh negative dan signifikan terhadap Indeks Saham Syariah (ISSI). Hal yang sama ditunjukkan dalam penelitian (Buyuksalvaci, 2010) dimana variabel suku bunga BI berpengaruh negative terhadap indeks saham di Turki. Berbeda dengan hasil penelitian dari (Abdullah, et al., 2014) yang menggunakan variabel harga minyak mentah dimana di beberapa negara kawasan Asia Tenggara hasilnya menunjukkan bahwa adanya hubungan positif antara harga minyak mentah dengan indeks saham syariah. Kemudian dalam (Pribawa, 2017) yang menguji inflasi, suku bunga BI, nilai tukar dan harga minyak dunia terhadap Jakarta Islamic Index Periode Januari 2011 - Desember 2016 dengan menggunakan Vector Error Correction Model (VECM) memaparkan bahwa pergerakan dari variabel inflasi direspon negative oleh JII namun variabel suku bunga BI, nilai tukar dan harga minyak dunia direspon positif oleh JII. Variabel suku bunga bank direspon paling cepat oleh JII diikuti variable nilai tukar, inflasi dan yang terakhir minyak dunia. Kondisi JII sendiri juga mengalami fluktuasi dimana menurut (Tanjung, 2014) JII periode 2 Maret 2009 - 30 Oktober 2013 dengan 1122 data harian terdistribusi tidak normal dimana hal ini akan menyebabkan keuntungan yang besar dan kerugian yang besar disuatu hari.

Berbeda dengan hasil penelitian (Fatrin dkk., 2018) menunjukkan bahwa antara variable suku bunga BI dengan ISSI dalam periode jangka pendek tidak memiliki hubungan namun dalam jangka panjang memiliki hubungan negative signifikan. Pada variable kurs dan ISSI terdapat hubungan jangka pendek namun sebaliknya dalam jangka panjang justru negative signifikan. Untuk variable inflasi dan ISSI terdapat hubungan jangka pendek dan jangka panjang. Variable harga minyak dunia dengan ISSI memiliki hubungan jangka pendek namun tidak pada jangka panjangnya. Kedua penelitian tersebut juga di dukung oleh hasil penelitian (Antonio, 2013). 
(Fitriany, 2015) melakukan penelitian Variabel Makro terhadap JII periode Januari 2004 - Desember 2013. Hasil penelitiannya menunjukkan bahwa terdapat perkembangan yang sangat fluktuatif, adapaun hasil dari analisis DOLS menunjukkan bahwa adanya pengaruh negative dan signifikan terhadap IHSG dan JII, padahal satu bulan sebelumnya dalam jangka pendek variabel nilai tukar memiliki pengaruh positif dan tidak signifikan terhadap variable IHSG dan JII. Pengaruh positif dan tidak signifikan ditunjukan oleh uang beredar terhadap IHSG dan JII, adapaun satu bulan sebelumnya jumlah uang beredar berpengaruh negative dan tidak signifikan terhadap IHSG dan JII. Namun dalam jangka pendek variable independen dapat menjelaskan hubungan terhadap IHSG dan JII secara simultan.

(Ayu, 2015) melakukan penelitian tentang pengaruh jumlah uang beredar, tingkat suku bunga SBI (BI Rate), inflasi, dan nilai tukar (kurs) terhadap Indeks Harga Saham di Jakarta Islamic Index (JII) dan Index Liquid 45 (LQ45). Penelitian tersebut menggunakan metode analitik deskriptif hasil dari uji PAM menunjukkan bahwa variable dependen JII dan LQ-45 mengalami kelambanan. Hasil uji menunjukkan bahwa inflasi memiliki pengaruh negative signifikan dan JUB memiliki pengaruh positif signifikan. Kedua variabel tersebut memiliki pengaruh lebih besar terhadap LQ-45 daripada JII. Menurut (Utami dan Herlambang, 2016) kurs memiliki pengaruh besar terhadap variabel-variabel ekonomi makro lainnya sehingga menjadikan kurs sebagai indicator penting. Kemudian (Afendi, 2017) menunjukkan bahwa adanya hubungan kurs rupiah dengan mata uang asing dengan harga saham dapat dilihat melalui pendekatan pasar barang, karena perubahan kurs akan mempengaruhi suatu perusahaan yakni pada pendapatan perusahaan yang nantinya akan mempengaruhi harga saham suatu perusahaan.seperti yang dinyatakan oleh Aisyah dan Khoiroh dalam Afendi 2017 bahwa nilai tukar akan emmpengaruhi perdagangan yang berkaitan dengan ekspor-impor karena depresiasi rupiah terhadap dollar AS menunjukkan bahwa nilai rupiah mengalami pelemahan sehingga penukaran mata uang dollar AS akan mendapatkan rupiah yang lebih banyak. Oleh karena itu ketika profitabilitas sebuah perusahaan turun maka akan menambah resiko investor dalam berinvestasi di bursa efek dalam (Utoyo dan Riduwan, 2016). Demikian juga yang akan terjadi pada pasar modal syariah.

Dari kajian literature diatas maka hubungan antar variable dalam penelitian ini dapat digambarkan dalam kerangka pemikiran sebagai berikut: 
Gambar 2. Kerangka Penelitian

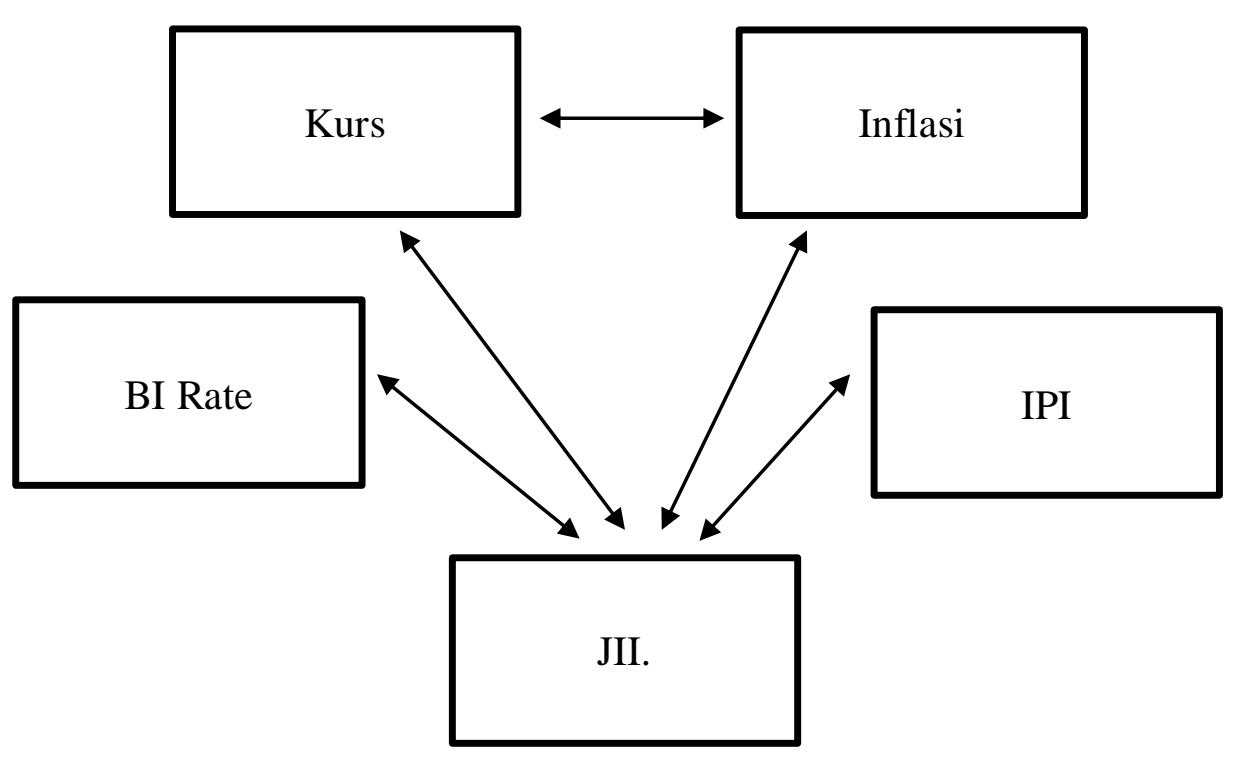

Sumber: (Data diolah, 2019)

Dari gambar 2 maka menunjukkan pola hubungan yang dinamis antar variable yang digunakan dalam penelitian ini.

\section{METODELOGI}

Pendekatan yang digunakan dalam penelitian ini merupakan pendekatan kuantitatif dengan jenis data time series bulanan. Penelitian ini merupakan kajian tentang pengaruh Kurs, Inflasi, Indeks Produksi Industri (IPI) dan BI Rate terhadap Jakarta Islamic Index (JII) selama kurun waktu 9 tahun. Ruang lingkup penelitian ini dilakukan di Indonesia. Sumber data penelitian merupakan jenis data sekunder yang didapatkan dari beberpa bulanan di Badan Pusat Statistik, Idx, dan Bank Indonesia. Periode data yang digunakan mulai bulan Januari 2006 sampai dengan bulan Desember 2015. Analisis data menggunakan Vector Autoregression (VAR) untuk menguji keenam variable yaitu Kurs rupiah terhadap dillar, Inflasi, Indeks Produksi Industri (IPI), BI Rate dan Jakarta Islamic Index (JII). Penggunaan VAR dilakukan karena model analisis data ini akan mampu menggambarkan adanya hubungan saling menyebabkan (kausalistis) diantara seluruh variable dalam system dengan menambahkan intercept, dimana terdapat asumsi bahwa seluruh variable merupakan variable endogen sehingga model dalam pengujian bersifat ateoritis (tidak berdasar teori). 
Tabel 1. Definisi Operasional

\begin{tabular}{|c|c|c|}
\hline Variabel & Definisi & Sumber \\
\hline Kurs & $\begin{array}{l}\text { Harga mata uang rupiah } \\
\text { terhadap dollar } \\
\text { perhitungan longan } \\
\text { dari nilai kurs tengah } \\
\text { Jual + Kurs beli)/2 }\end{array}$ & $\frac{\text { www.bi.go.id }}{\text { Bank Indonesia }}$ \\
\hline Inflasi & $\begin{array}{lcr}\text { Harga-harga produk } & \text { secara } \\
\text { keseluruhan yang } & \text { sedang } \\
\text { mengalami peningkatan } & \end{array}$ & $\frac{\text { www.bi.go.id }}{\text { Bank Indonesia }}$ \\
\hline Indeks Produksi Industri & $\begin{array}{l}\text { Indicator ekonomi dari produksi } \\
\text { output riil }\end{array}$ & $\begin{array}{l}\text { Badan Pusat Statistik } \\
\text { www.bps.go.id }\end{array}$ \\
\hline BI Rate & $\begin{array}{ll}\text { Kebijakan moneter } & \text { yang } \\
\text { diambil dan diputuskan } & \text { oleh } \\
\text { Bank Indonesia } & \end{array}$ & $\frac{\text { www.bi.go.id }}{\text { Bank Indonesia }}$ \\
\hline Jakarta Islamic Index & $\begin{array}{l}\text { Perhitungan dari indeks rata-rata } \\
\text { saham syariah }\end{array}$ & $\begin{array}{l}\text { idx } \\
\text { www.idx.co.id/ }\end{array}$ \\
\hline
\end{tabular}

Sumber: (data diolah oleh peneliti, 2019)

Data diolah melalui tiga tahapan yakni uji Stasioneritas, uji lag optimum, uji kointegrasi dan yang terakhir uji Impulse Response Function.

\section{HASIL DAN PEMBAHASAN}

Uji Stasioneritas. Dalam uji ini perlu dilakukan menggunakan uji augmented Dickey-fuller (ADF) dimana data menjadi tidak stasioner jika nilai absolute statistic $t$ lebih kecil dari nilai kritis pada table MacKinnon pada berbagai tingkat kepercayaan (1\%, 5\% dan 10\%) dan jika nilai prob > 0,05 maka tidak stasioner. (Winarno, 2007). Namun jika yang terjadi adalah sebaliknya dimana ADF > nilai kritis tingkat kepercayaan (1\%, 5\%. Dan 10\%) menunjukkan tidak adanya akar unit atau data dinyatakan stasioner.

Hasil dari Uji ADF Menggunakan Intercept pada tingkat level

Tabel 2. Hasil Uji ADF

\begin{tabular}{l|c|c|c|c|c}
\hline Variabel & Unit Root & $\begin{array}{c}\text { ADF t- } \\
\text { Statistik }\end{array}$ & $\begin{array}{c}\text { Ms Kinnon } \\
\text { Critical Value } \\
\mathbf{5} \%\end{array}$ & Prob & Ket \\
\hline Inflasi & Level & $-8,359000$ & -2.886074 & 0,0000 & Stasioner \\
\hline IPI & Level & -13.38346 & -2.886074 & 0.0000 & Stasioner \\
\hline JII & Level & -9.626694 & -2.886074 & 0.0000 & Stasioner \\
\hline KURS & Level & -10.28611 & -2.886509 & 0.0000 & Stasioner \\
\hline BI RATE & Level & -3.285006 & -2.886290 & 0.0178 & Stasioner \\
\hline
\end{tabular}

Sumber: (diolah, 2019) 
Dari table 1 dapat dilihat bahwa ADF test untuk variabel JII, KURS, Inflasi, IPI, dan BI Rate $<$ nilai kritis 5\% artinya sudah stasioner pada level.

Uji Panjang Lag Optimal. Panjang lag optimal dilakukan untuk mengetahui lama dari periode pengaruh suatu variable endogen terhadap variable endogen lain. Nilai-nilai dapat dilihat dari table 2 hasil uji panjang lag optimal dibawah ini.

Sample: 1120

Tabel 3. Hasil Uji Panjang Lag Optimum

Included observations: 118

\begin{tabular}{ccccccc}
\hline \hline Lag & LogL & LR & FPE & AIC & SC & HQ \\
\hline \hline 0 & -2671.996 & NA & $3.49 \mathrm{e}+13$ & 45.37282 & 45.49022 & 45.42049 \\
1 & -2067.566 & 1147.392 & $1.90 \mathrm{e}+09$ & 35.55197 & $36.25638^{*}$ & $35.83798^{*}$ \\
2 & -2037.625 & $54.30031^{*}$ & $1.75 \mathrm{e}+09 *$ & $35.46822^{*}$ & 36.75964 & 35.99257 \\
\hline \hline
\end{tabular}

Sumber: (data diolah, 2019)

Dari table 2 dapat diketahui lag 2 merupakan lag optimal. Pemilihan lag 2 sebagai lag optimal karena berdasarkan hasil eviews bahwa jumlah bintang terbanyak terdapat pada lag 2.

Hasil Uji Stabilitas VAR. VAR condition stability check digunakan untuk menguji stabil atau tidaknya estimasi VAR yang telah ditentukan maka yang perlu dilakukan yakni berupa roots of characteristic polynominal. Suatu model VAR dikatakan stabil jika seluruh roots nya memiliki modulus < 1 (Gujarati, 2003). Tabel berikut merupakan hasil uji stabilitas VAR:

Tabel 4. Hasil Uji Stabilitas Model

\begin{tabular}{ll}
\hline \hline \multicolumn{1}{c}{ Root } & Modulus \\
\hline \hline $0.951336-0.038418 \mathrm{i}$ & 0.952111 \\
$0.951336+0.038418 \mathrm{i}$ & 0.952111 \\
0.871495 & 0.871495 \\
$0.643139-0.067660 \mathrm{i}$ & 0.646688 \\
$0.643139+0.067660 \mathrm{i}$ & 0.646688 \\
0.540885 & 0.540885 \\
-0.353290 & 0.353290 \\
-0.168378 & 0.168378 \\
$0.068484-0.111478 \mathrm{i}$ & 0.130834 \\
$0.068484+0.111478 \mathrm{i}$ & 0.130834 \\
\hline \hline
\end{tabular}

Sumber: Diolah 2019 
Dari tabel diatas menunjukkan bahwa tidak adanya nilai akar karakteristik dan modulus yang $>1$. Sedangkan dari gambar 1 . Semua titik invers roots of AR polynomial tidak ada yang berada di luar dari lingkaran.

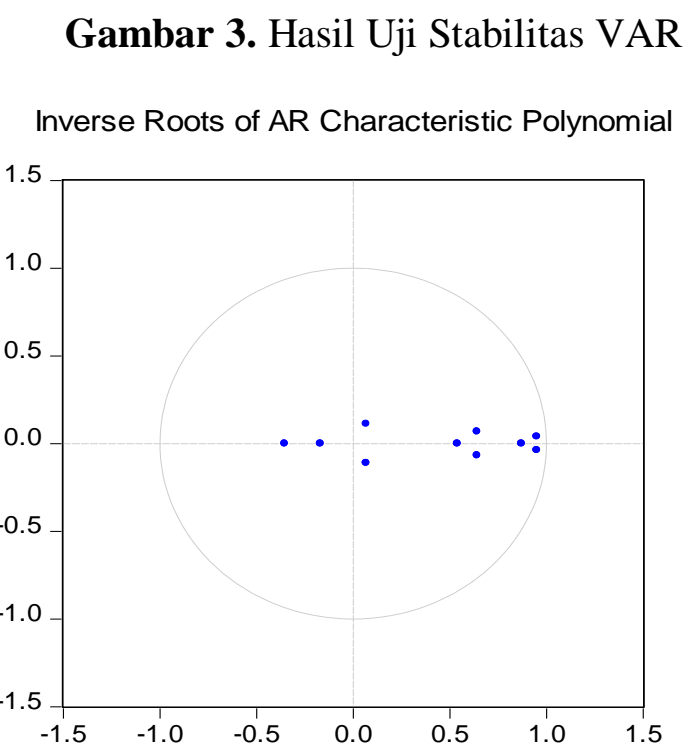

Sumber: (Diolah, 2019)

Hasil Analisis Causality Grager. Hubungan kausalitas antara variable dapat diketahui melalui uji kausalitas granger. (Nachrowi, 2006). Hubungan timbal balik dapat diketahui melalui hasil uji di table berikut:

Tabel 5. Hasil Uji Causality Grager

\begin{tabular}{|c|c|c|c|}
\hline Null Hypothesis: & Obs & F-Statistic & Prob. \\
\hline KURS does not Granger Cause JII & \multirow[t]{2}{*}{118} & 0.35636 & 0.7010 \\
\hline JII does not Granger Cause KURS & & 3.95178 & 0.0219 \\
\hline INFLASI does not Granger Cause JII & \multirow[t]{2}{*}{118} & 4.74630 & 0.0105 \\
\hline JII does not Granger Cause INFLASI & & 0.83269 & 0.4375 \\
\hline IPI does not Granger Cause JII & \multirow[t]{2}{*}{118} & 0.11803 & 0.8888 \\
\hline JII does not Granger Cause IPI & & 0.27032 & 0.7636 \\
\hline BI_RATE does not Granger Cause JII & \multirow[t]{2}{*}{118} & 2.90471 & 0.0589 \\
\hline JII does not Granger Cause BI_RATE & & 5.49250 & 0.0053 \\
\hline INFLASI does not Granger Cause KURS & \multirow[t]{2}{*}{118} & 0.05027 & 0.9510 \\
\hline KURS does not Granger Cause INFLASI & & 0.15208 & 0.8591 \\
\hline
\end{tabular}

Sumber: (diolah, 2019) 
Jika nilai probabilitas yang terdapat dalam penelitian kasualitas granger lebih besar dari 0,05 maka disimpulkan tidak terjadi kasualitas antar variabel. Dari tabel 4 dapat dilihat bahwa variabel JII secara statistic signifikan mempengaruhi Kurs dengan nilai 0,0219<0,05 sehingga menolak hipotesis nol. Artinya ketika JII mengalami kenaikan atau penurunan maka akan mempengaruhi nilai Kurs Rupiah, namun hubungan ini hanya terjadi satu arah dimana ketika nilai Kurs mengalami kenaikan ataupun penurunan maka tidak akan mempengaruhi JII hal ini ditunjukkan dengan nilai statistic nya pada tabel 4 yaitu $0,710>$ 0,05 . Begitu juga dengan variabel Inflasi terhadap JII yang memiliki nilai probabilitas $0,0105<0,05$ dimana artinya Inflasi mempengaruhi JII namun hanya memiliki hubungan satu arah dimana variabel JII secara statistic tidak signifikan mempengaruhi Inflasi terlihat pada tabel nilai probabilitasnya yaitu $0,4375>0,05$. Variabel JII secara statistic signifikan mempengaruhi BI Rate dengan nilai probabilitas 0,0053<0,05 namun tidak terjadi hubungan sebaliknya dimana nilai probabilitasnya 0,0589>0,05 yang artinya BI Rate tidak signifikan mempengaruhi JII. Sedangkan variabel IPI dan JII sama-sama tidak saling mempengaruhi baik secara searah maupun dua arah. Begitu juga dengan variabel Inflasi dan Kurs, keduanya tidak saling mempengaruhi.

Hasil Uji Kointegrasi. Uji ini dilakukan untuk mengetahui hubungan jangka panjang dan pendek seluruh variable. Penelitian ini menggunakan uji johansen dengan tingkat keyakinan $5 \%$ ataupun $1 \%$ sebagai perbandingan dengan nilai trace. Adapun jika nilai trance statisticnya $<$ nilai kritis maka dapat disimpulkan bahwa kedua variabel tidak saling berkointegrasi (Winarno, 2007). Melalui pengujian kointegrasi Johansen's pada table 5 dibawah ini terindikasi bahwa kedua variable saling berkointegrasi, karena bias dilihat bahwa trace statistic > critical value pada tingkat keyakinan 5\%.

Tabel 6. Uji Kointegrasi

Unrestricted Cointegration Rank Test (Trace)

\begin{tabular}{ccccc}
\hline $\begin{array}{c}\text { Hypothesized } \\
\text { No. of CE(s) }\end{array}$ & Eigenvalue & $\begin{array}{c}\text { Trace } \\
\text { Statistic }\end{array}$ & $\begin{array}{c}\mathbf{0 . 0 5} \\
\text { Critical Value }\end{array}$ & Prob.** \\
\hline \hline None * & 0.257921 & 73.30474 & 69.81889 & 0.0256 \\
At most 1 & 0.125637 & 38.40363 & 47.85613 & 0.2847 \\
At most 2 & 0.106258 & 22.69529 & 29.79707 & 0.2613 \\
At most 3 & 0.060566 & 9.551764 & 15.49471 & 0.3168 \\
At most 4 & 0.018979 & 2.241855 & 3.841466 & 0.1343 \\
\hline \hline
\end{tabular}

Trace test indicates 1 cointegrating eqn(s) at the 0.05 level

* denotes rejection of the hypothesis at the 0.05 level

**MacKinnon-Haug-Michelis (1999) p-values

Sumber: (data diolah, 2019)

Berdasarkan tabel di atas dapat dilihat bahwa nilai trace statistic dan maximum eigenvalue pada $r=0$ lebih kecil dari critical value dengan tingkat signifikansi $5 \%$. Hal ini berarti hipotesis nol yang menyatakan bahwa tidak ada kointegrasi diterima dan hipotesis 
alternatif yang menyatakan bahwa ada kointegrasi ditolak. Berdasarkan analisis ekonometrik di atas dapat dilihat bahwa di antara keempat variabel dalam penelitian ini, terdapat satu kointegrasi pada tingkat signifikansi 5\%. Dengan demikian, dari hasil uji kointegrasi mengindikasikan bahwa di antara pergerakan JII, Kurs, Inflasi, IPI dan BI Rate tidak memiliki hubungan stabilitas/keseimbangan dan kesamaan pergerakan dalam jangka panjang.

\section{Analisis Impulse Respond dan Variance Decomposition}

Gambar 4. Hasil Uji Impulse Respond
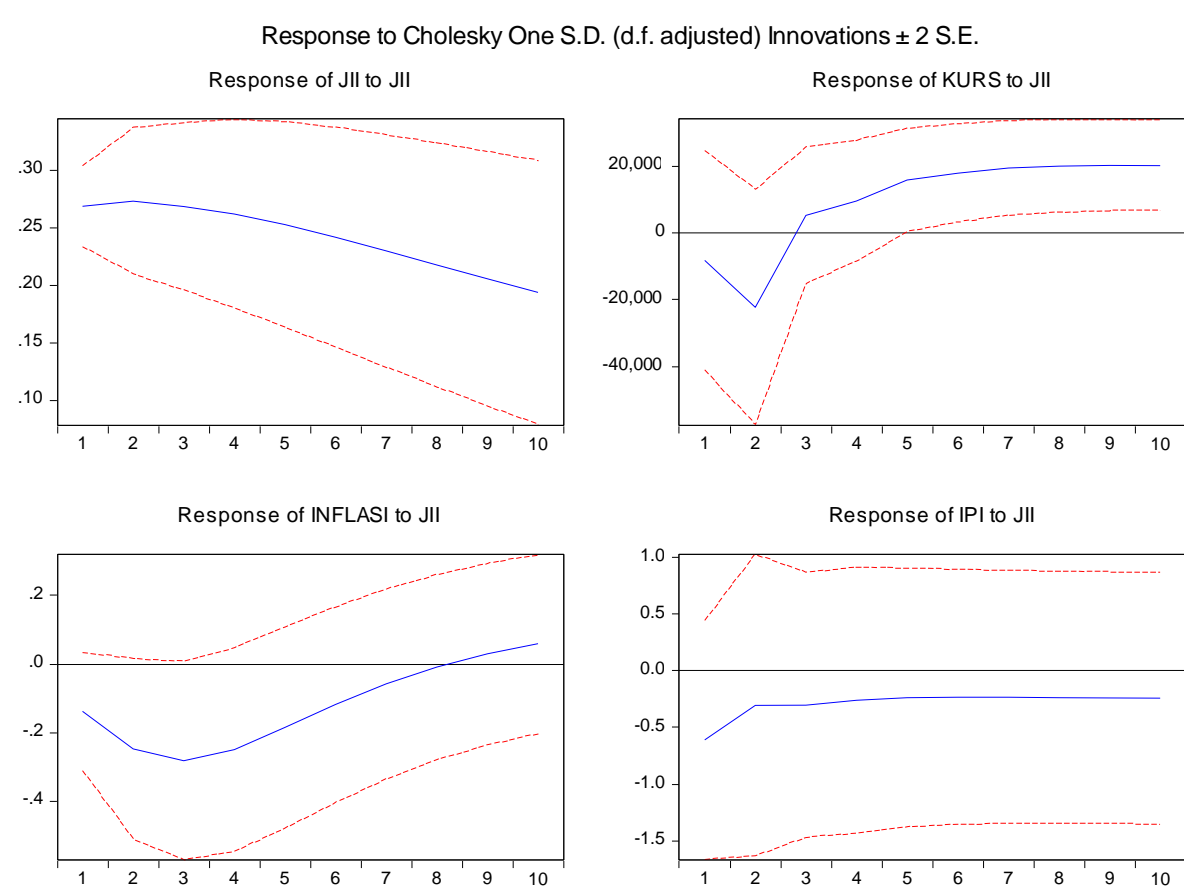

Response of BI_RATE to JI

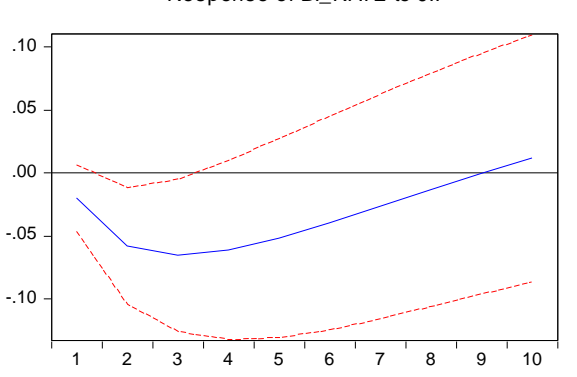


Analisis impulse-response dapat menggunakan fungsi impulse-response (IRF). Berdasarkan Gambar 3 terdapat 5 plot IRF untuk 10 periode ke depan yang mana menjelaskan secara visual tanggapan (response) suatu variabel yang timbul karena adanya shock (impulse) sebesar 1 standar deviasi baik dari dirinya sendiri ataupun dari variabel lainnya.

Berdasarkan Gambar 3 bahwa analisis IRF dari JII untuk 10 periode ke depan sebagai berikut: (1) Respon tingkat JII terhadap guncangan dari dirinya sendiri pada periode pertama yaitu 0.269 yang mana berbeda pada saat periode 2 hingga periode 10 mengalami penurunan. Hal ini berarti bahwa setelah periode 2 reaksi tingkat JII terhadap guncangan dari dirinya sendiri cenderung menjadi lemah. (2) Respon tingkat JII terhadap guncangan dari kurs rupiah pada periode 1 ke periode 2 menurun dari -8133 ke -22181 yang artinya menurun sebesar 14048. Pada periode ketiga mengalami kenaikan menuju positif pada tingkat 5312 dan terus mengalami kenaikan hingga periode 10. Stabilitas terjadi mulai pada periode ke 5. (3) Respon yang didapatkan JII terhadap Inflasi pada periode pertama hingga periode 8 berada pada sisi negative, baru pada periode 9 hingga periode 10 mengalami kenaikan hingga mencapai sisi positif berada di atas garis horizontal dimana berujung pada nilai 0,06 . (4) Respon yang didapatkan JII terhadap IPI cenderung bernilai negatif. Hal ini dimaksudkan bahwa jika terjadi guncangan sebesar 1 standar deviasi dari nilai IPI maka tingkat JII akan bereaksi negatif terhadap IPI. (5) Respon yang diterima dari tingkat JII terhadap BI Rate pada periode pertama hingga periode 9 berada pada sisi negative dan mengalami penurunan hingga periode 3 , namun pada periode 4 mengalami kenaikan hingga mencapai pada sisi positif yakni menuju garis horizontal pada titik 0.00 .

Setelah analisis terhadap perilaku dinamis model melalui impulse respon function, maka selanjutnya akan dilihat karakteristik model melalui Variance Decomposition.

Tabel 7. Hasil Varience Decomposition of JII

\begin{tabular}{ccccccc} 
Period & S.E. & JII & KURS & INFLASI & IPI & BI_RATE \\
\hline \hline 1 & 0.268939 & 100.0000 & 0.000000 & 0.000000 & 0.000000 & 0.000000 \\
2 & 0.389357 & 97.04134 & 0.818482 & 1.924219 & 0.027461 & 0.188499 \\
3 & 0.484740 & 93.32831 & 1.718485 & 4.073634 & 0.125172 & 0.754404 \\
4 & 0.565956 & 89.92770 & 2.552379 & 5.814562 & 0.233100 & 1.472255 \\
5 & 0.635893 & 87.04414 & 3.253200 & 7.183589 & 0.332661 & 2.186409 \\
6 & 0.696364 & 84.64016 & 3.835044 & 8.258830 & 0.418399 & 2.847572 \\
7 & 0.748758 & 82.63722 & 4.312760 & 9.114008 & 0.489589 & 3.446426 \\
8 & 0.794265 & 80.95463 & 4.705610 & 9.804882 & 0.547364 & 3.987509 \\
9 & 0.833882 & 79.52509 & 5.029967 & 10.37284 & 0.593308 & 4.478794 \\
10 & 0.868453 & 78.29542 & 5.299622 & 10.84770 & 0.629066 & 4.928185 \\
\hline
\end{tabular}

Sumber: (data diolah, 2019)

Dari hasil tabel menunjukkan bahwa perkiraan error variance pertama seluruhnya (100\%) dijelaskan oleh JII itu sendiri sedangkan variabel Kurs, Inflasi, IPI, BI Rate tidak berpengaruh. Periode berikutnya, JII masih didominasi oleh perubahan JII itu sendiri yakni sebesar $97.04 \%$ kemudian disusul oleh $1.92 \%$ di dominasi oleh Inflasi di susul variabel Kurs 
$0.82 \%$ kemudian BI Rate 0.19 serta posisi terakhir oleh IPI $0.03 \%$. Setiap periodenya masing-masing variabel memberikan konstribusi yang berbeda-beda kepada JII hingga periode kesepuluh. Konstribusi yang diberikan variabel Kurs, Inflasi, IPI dan BI Rate terus meningkat hingga periode kesepuluh dimana setiap periodenya dengan angka yang bervariasi. Nilai hubungan terbesar pada periode kesepuluh berasal dari variabel inflasi yaitu sebesar $10.85 \%$ dan nilai hubungan terkecil pada periode yang sama berasal dari variabel IPI sebesar $0.63 \%$. Berdasarkan nilai error variance dan analisis di atas dapat disimpulkan bahwa JII lebih banya dipengaruhi oleh Inflasi kemudian disusul oleh Kurs, kemudian BI Rate dan yang terakhir IPI.

Dari hasil uji data diatas menunjukkan bahwa beberapa variable ada yang saling mempengaruhi dan tidak mempengaruhi. Untuk variable yang saling mempengaruhi dalam jangka pendek yaitu variabel JII terhadap Kurs, Inflasi terhadap JII hal ini didukung oleh penelitian (Mulyani, 2014) (Sunardi dan Ula, 2017), JII terhadap BI Rate diukung penelitian (Pribawa 2017). Sedangkan yang tidak berpengaruh Kurs terhadap JII, BI Rate terhadap JII, IPI dan JII, Inflasi dan Kurs. Hal ini disebabkan karena fluktuasi pergerakan antar variable yang sangat berbeda antara satu dengan yang lainnya. Selain itu guncangan yang diterima JII hanya didominasi oleh JII itu sendiri sedangkan variable lain dalam penelitian ini tidak ada yang lebih dari $10.58 \%$ dimana merupakan angka terbesar yang dihasilkan dari Inflasi. Hal ini disebabkan karena ada berbagai banyak factor yang mempengaruhi JII itu sendiri selain dari variable yang digunakan dalam penelitian ini.

\section{KESIMPULAN}

Variabel JII secara statistic signifikan mempengaruhi Kurs, namun hubungan ini hanya terjadi satu arah dimana ketika nilai Kurs mengalami kenaikan ataupun penurunan maka tidak akan mempengaruhi JII. Begitu juga dengan variabel Inflasi terhadap JII dimana artinya Inflasi mempengaruhi JII namun hanya memiliki hubungan satu arah dimana variabel JII secara statistic tidak signifikan mempengaruhi Inflasi. Variabel JII secara statistic signifikan mempengaruhi BI Rate namun tidak terjadi hubungan sebaliknya. Sedangkan variabel IPI dan JII sama-sama tidak saling mempengaruhi baik secara searah maupun dua arah. Begitu juga dengan variabel Inflasi dan Kurs, keduanya tidak saling mempengaruhi.

Respon tingkat JII terhadap guncangan dari dirinya sendiri pada periode pertama yang mana berbeda pada saat periode 2 hingga periode 10 mengalami penurunan. Hal ini berarti bahwa setelah periode 2 reaksi tingkat JII terhadap guncangan dari dirinya sendiri cenderung menjadi lemah. Respon tingkat JII terhadap guncangan dari kurs rupiah pada periode $1 \mathrm{ke}$ periode 2 menurun. Pada periode ketiga mengalami kenaikan menuju positif dan terus mengalami kenaikan hingga periode 10. Stabilitas terjadi mulai pada periode ke 5. Respon yang didapatkan JII terhadap Inflasi pada periode pertama hingga periode 8 berada pada sisi negative, baru pada periode 9 hingga periode 10 mengalami kenaikan hingga mencapai sisi positif. Respon yang didapatkan JII terhadap IPI cenderung bernilai negatif. Hal ini dimaksudkan bahwa jika terjadi guncangan sebesar 1 standar deviasi dari nilai IPI maka tingkat JII akan bereaksi negatif terhadap IPI. Respon yang diterima dari tingkat JII terhadap BI Rate pada periode pertama hingga periode 9 berada pada sisi negative dan mengalami penurunan hingga periode 3 , namun pada periode 4 mengalami kenaikan hingga mencapai pada sisi positif. 
Setiap periodenya masing-masing variabel memberikan konstribusi yang berbedabeda kepada JII hingga periode kesepuluh. Konstribusi yang diberikan variabel Kurs, Inflasi, IPI dan BI Rate terus meningkat hingga periode kesepuluh dimana setiap periodenya dengan angka yang bervariasi. Nilai hubungan terbesar pada periode kesepuluh berasal dari variabel inflasi yaitu sebesar $10.85 \%$ dan nilai hubungan terkecil pada periode yang sama berasal dari variabel IPI sebesar $0.63 \%$. Berdasarkan nilai error variance dan analisis di atas dapat disimpulkan bahwa JII lebih banya dipengaruhi oleh Inflasi kemudian disusul oleh Kurs, kemudian BI Rate dan yang terakhir IPI.

\section{DAFTAR PUSTAKA}

Abdullah, A., Saiti, B., dan Masih, A. (2014). The Impact of Crude Oil Price on Islamic Stock Indicies of South East Asian (SEA) Countries: A Comparative Analysis. Munich Personal RePEc Archive (MPRA), 56957.

Afendi, A. (2017). Pengaruh Variabel Makro Ekonomi Terhadap Indeks Saham di Jakarta Islamic Index (JII) (Periode 2012-2016). Jurnal Manajemen dan Bisnis, Vol.13 No.2.

Antonio, M. (2013). The Islamic Capital Market Vilatiliry: A Comparative Study Between in Indonesia and Malaysia. Bulletin of Monetary, Economics and Banking.

Ayu, N. E. (2015). Pengaruh Inflasi, Jumlah Uang Beredar (JUB), Tingkat Suku Bunga SBI (BIRATE), dan Nilai Tukar (KURS) terhadap Indeks Harga Saham di Jakarta Islamic Index (JII) dan Index Liquid-45 (LQ-45) (Periode Januari 2006 - Desember 2014). Fakultas Ekonomi dan Bisnis dan Agama ISlam Universitas Muhammadiyah Surakarta.

Beik, I. S., dan Fatmawati, S. W. (2014). Pengaruh Indeks Harga Saham Syariah Internasional dan Variabel Makroekonomi Terhadap Jakarta Islamic Index. Jurnal Al Iqtishad, Vol. VI No.2 Juli.

Buyuksalvaci. (2010). The Effect of Macroeconomics Variable on Stock Return: Evidance from Turkey. European Jpurnal On Social Science, 14 (3): 440-416.

Fatrin, T. N., Ardana, Y., dan Wulandari. (2018). Faktor-Faktor yang Mempengaruhi Holding Period Saham. Benefit Jurnal Manajemen dan Bisnis, 89-97.

Fitriany, R. (2015). Pengaruh Variabel Makroekonomi Terhadap Indeks Harga Saham Gabungan (IHSG) dan Jakarta Islamic INdex (JII). Universitas Jember , 86.

Ginting, M., dan Sulasmiyati, S. (2016). Pengaruh Tingkat Suku Bunga, Nilai Tukar dan Inflasi Terhadap Harga Saham (Studi Pada Sub-Sektor Perbankan di Bursa Efek Indonesia Periode 2011-2015). Jurnal Administrasi Bisnis (JAB), 35(2):77-85.

Green, W. (2000). Econometric Analysis, Fourth Edition. New Jersey: Prentice Hall Inc.

Gujarati, N. D. (2003). Ekonometrika Dasar, Terjemahan: Sumarno Zain. Jakarta: Erlangga.

Kasmir. (2012). Bank dan Lembaga Keuangan Lainnya. Jakarta: PT. Raja Grafindo Persada.

Kewal, S. S. (2012). Pengaruh Inflasi, Suku Bunga, Kurs dan Pertumbuhan PDB Terhadap Indeks Harga Saham Gabungan. Jurnal Economia, Volume 8 Nomor 1 April .

Kismawardi, E. R. (2013). Pengaruh Variabel Makroekonomi terhadap Jakarta Islamic Index. Intitute Agama Islam Negeri Sumatera Utara, 22. 
Mulyani , N. (2014). Pengaruh Inflasi, Suku Bunga, NIlai Tukar Rupiah dan Produk Domestik Bruto Terhadap Jakarta Islamic Index. Jurnal Bisnis dan Manajemen Eksekutif, 1(10).

Nachrowi, D. N. (2006). Ekonometrika, untuk Analisis Ekonomi dan Keuangan. Jakarta: Lembaga Penerbit FE UI.

Otoritas Jasa Keuangan. (2019, November 20). Statistik Pasar Modal. Retrieved from Otoritas Jasa Keuangan: www.ojk.go.id

Pribawa. (2017). Guncangan Variabel Makroekonomi Terhadap Jakarta Islamic Index (JII). Cakrawala: Jurnal Studi Islam.

Rachmawati, M., dan Laila, N. (2015). Faktor Makroekonomi yang Mempengaruhi Pergerakan Harga Saham Pada Indeks Saham Syariah Indonesia (ISSI) di Bursa Efek Indonesia. Jurnal Ekonomi Syariah Teori dan Terapan .

Romansyah. (2015). Pasar Modal Dalam Perspektif Islam. Mazahib: Jurnal Pemikiran Hukum Islam, Vol.14 No.1.

Rusbariandi, P. S. (2012). Analisis Pengaruh Tingkat Inflasi, Harga Minyak Dunia, Harga Emas Dunia dan Kyrs Rupiah terhadap Pergerakan Jakarta Islamic Index di Bursa Efek Indonesia. Prosiding Seminar Nasional Forum Bisnis \& Keuangan , 724-740.

Sakti, M. P. (2013). Relantionship between Stock Prices and Macroeconomic Variabel: Evidance from Jakarta Stock Exchange Islamic Index. Global Review of Islamic and Business.

Samsul, M. (2016). Pasar Modal dan Manajemen Portofolio. Jakarta: Erlangga.

Shidiq, A., dan Setiawan, A. (2015). Analisis Pengaruh Suku Bunga SBI, Uang Beredar, Inflasi dan Nilai Tukar Terhadap Indeks Harga Saham Jakarta Islamic Index (JII). Jurnal Ekonomi dan Perbankan Syariah, Vol.3 No.2. 25-46.

Suciningtias, S., dan Khoiroh, R. (2015). Analisis Dampak Variabel Makro Ekonomi Terhadap Indeks Saham Syariah Indonesia (ISSI). Conference in Business, Accounting and Management (CBAM), 398-412.

Sunardi , N., dan Ula, L. (2017). Pengaruh BI Rate, Inflasi dan Kurs Terhadap Indeks Harga Saham Gabungan (IHSG). Jurnal Sekuritas: Saham, Ekonomi, Keuangan dan Investasi 1 (2), 27 - 41. ISSN: 2581-2696.

Tanjung. (2014). Volatility of Jakarta Islamic Indeks. Jurnal Al iqtishad, Vol.6 No.2.

Utami, T., dan Herlambang, L. (2016). Pengaruh Variabel Makro Ekonomi Terhadap Jakarta Islamic Index (JII) Periode Januari 2010 hingga November 2015. Jurnal Ekonomi Syariah Teori dan Terapan, Vol.3 No.1.

Utoyo, N. N., dan Riduwan, A. (2016). Pengaruh Tingkat Inflasi, Suku Bunga, Harga Emas Dunia dan Kurs Pada JII. Jurnal Ilmu dan Riset Akuntansi, Vol.5 No.8.

Wastriati. (2010). Analisis Pengaruh Variabel Makroekonomi terhadap Nilai Jakarta Islamic Index. Jakarta: Universitas Islam Negeri.

Winarno, B. (2007). Kebijakan Publik: Teori dan Proses. Yogyakarta: Med Press (Anggota IKAPI). 